\title{
Evaluation of proximate composition, microbial load and sensory characteristics of instant holat as traditional spice in North Sumatra, Indonesia
}

\author{
WAHYU HARYATI MASER ${ }^{1, \vartheta}$, MUHAMMAD ZULHAM EFENDI SINAGA ${ }^{2}$ \\ ${ }^{1}$ Department of Food Science and Technology, Faculty of Agriculture, Universitas Sumatera Utara. Jl. Prof. A. Sofyan No. 3, Kampus USU, Medan \\ 20155, North Sumatra, Indonesia. Tel.: +62-61-8213236, Fax.: +62-61-8211924. `email: maser.wahyuharyati@usu.ac.id. \\ ${ }^{2}$ Department of Chemistry, Faculty of Mathematics and Natural Sciences, Universitas Sumatera Utara. J1. Bioteknologi No. 1, Kampus USU, Medan \\ 20155, North Sumatra, Indonesia
}

Manuscript received: 6 June 2021. Revision accepted: 25 July 2021.

\begin{abstract}
Maser WH, Sinaga MZE. 2021. Evaluation of proximate composition, microbial load and sensory characteristics of instant holat as traditional spice in North Sumatra. Biodiversitas 22: 3440-3445. Holat is the name of traditional food from North Sumatra, Indonesia which has astringent flavor derived from the bark of Phyllanthus emblica. The aims of this study were to determine the proximate composition and evaluate microbial load, and sensory characteristics of instant holat spice. There were 12 treatments, namely the combination of different amounts of bark $(15 \mathrm{~g}, 25 \mathrm{~g}, 35 \mathrm{~g}, 45 \mathrm{~g})$ and drying time $(20 \mathrm{~h}, 22 \mathrm{~h}, 24 \mathrm{~h})$. The proximate composition (moisture, ash, protein, fat, crude fiber, fat, and total carbohydrate content), microbial analysis (total plate count; yeast and mold count), and sensory characteristics (aroma, color, taste, and overall acceptability) were carried out. The results showed that water, protein, fat, crude fiber, and total carbohydrates contents were all significantly different $(\mathrm{p}<0.05)$, except ash content. There was no yeast, mold, and bacterial growth on total plate count. There were no significant differences in all sensory characteristics (aroma, color, taste, and overall acceptability) of instant holat before and after brewing ( $\mathrm{p} \geq 0.05$ ). The treatment of F4-24 was the best formula and has the highest score that might be developed as a product of instant holat spice. Further study should be conducted to determine the effect by increasing the amount of bark and evaluating its bioactivity.
\end{abstract}

Keywords: Instant holat spice, Phyllanthus emblica bark, proximate composition, sensory characteristics, North Sumatra

\section{INTRODUCTION}

Holat is the name of traditional Indonesian cuisine from Padang Bolak, North Sumatera (Khoiriyah et al. 2015; Paluseri et al. 2017). The word holat is derived from the word chelate, which means astringent, and refers to the taste of the key ingredient (Damanik and Sinaga 2020; Pulungan et al. 2020). The essential ingredient of holat is the bark of the Indian gooseberry (Phyllanthus emblica) (Paluseri et al. 2017; Maser and Marsella 2019).

Phyllanthus emblica, known as kimalaka (Indonesian), is widespread in Indonesia (Uji 2007). Southern North Sumatra with a rainfall of 2000-2500 mm/year on mixed dryland agriculture and humic acrisol soil types is one of the regions that are overtaken by this plant, (Khoiriyah et al. 2015). This plant is distributed in tropical and subtropical areas such as Pakistan, Uzbekistan, Burma, Nepal, Bangladesh, Bhutan, Sri Lanka, South East Asia, and China, as well as the Malay Peninsula (Khan 2009; Huabprasert et al. 2012; Dasaroju and Gottumukkala 2014; Priya and Islam 2019).

Phyllanthus emblica (Euphorbiaceae) is a moderate deciduous tree that can grow to a height of 10-18 $\mathrm{m}$ (Khan 2009). This plant has a greenish-grey bark and greenishyellow flowers that grow in axillary clusters. The branchlets reach a length of $40 \mathrm{~cm}$ long and have more than 100 leaves clustered in them. The bark is brown and peels off into little uneven flakes (Gaire and Subedi 2014).

Indian gooseberry has been utilized as traditional medicine, functional food, and cosmetic (Sripanidkulchai and Fangkrathok 2014). The fruit is the most commonly used as a food ingredient, while the barks are frequently used as medicine (Kumar et al. 2012; Priya and Islam 2019). The bark contains terpenes, phytosterols, and terpenoids (Deepak and Gopal 2014), as well as polyphenols, flavonoids, tannins, ellagic acid, and gallic acid, which function as antioxidants and radical scavengers, and antimicrobial (Iamsaard et al. 2014; Chaphalkar et al. 2017; Ahmad et al. 2021). Holat has the potential as functional food and nutritious cuisine (Pulungan et al. 2020).

Instant food is a simple food product that may be prepared quickly and easily, with ingredients that have been pre-mixed so that it may be conveniently and readily available (Ali et al. 2012; Monteiro et al. 2014; Munasinghe et al. 2015; Dhiman et al. 2017). The availability of instant holat spice makes cooking easier and can preserve Indonesian traditional food culture. Two formulations have been used to investigate the sensory properties of instant holat spice (Maser and Marsella 2019). However, the proximate composition and microbial analysis have not been performed. Therefore, the purpose of this study was to examine the proximate composition, microbial analysis, and sensory characteristics of instant holat spice. 


\section{MATERIALS AND METHODS}

\section{Materials}

The bark of Phyllanthus emblica (collected from plant with stem diameter of $6-9 \mathrm{~cm}$, the bark shaving of 40-60 $\mathrm{g} / \mathrm{stem}$ ) was obtained from the forest of Padang Bolak, North Sumatra. The analytical grade chemicals and solvents were purchased from Merck and Sigma Aldrich, USA.

\section{Sample preparations}

Four different compositions of instant holat spice were used in this study (Table 1$)$. Oil (15 mL/50 g onion) was used to fry the smooth onion until it was slightly brown and fragrant. The ginger, lemongrass, and garlic were mashed together. The leeks and celery were cut into small pieces. All ingredients were mixed as in Table 1) and boiled for about 5 minutes in $400 \mathrm{~mL}$ of water until the initial boiling. The mixture of spices was dried in a cabinet drier at $60^{\circ} \mathrm{C}$ for a predetermined time ( 20 hours, 22 hours, and 24 hours) and refrigerated in an airtight packing.

\section{Proximate composition}

The proximate composition of instant holat spice was evaluated in duplicate. The protein content was determined using the Kjeldahl method (AOAC 2011). AOAC methods were used to analyze moisture, fiber, fat, and ash contents (AOAC 2011). Carbohydrate content was determined by subtracting 100 from the total moisture, fat, ash, and protein content (AOAC 2011).

\section{Microbial analysis}

Microbial analysis was performed using the conventional plate count.as described by Maturin and Peeler (2001) for total plate count, yeast and mold.

\section{Sensory evaluation}

Sensory characteristics were conducted with 80 untrained panelists from staff and students of the Food Science and Technology Study Program, USU. A 7-point hedonic scale (7-like very much and 1-dislikes very much) was used to evaluate four aspects (taste, odor, color, and overall acceptability) of sensory testing (Yusof et al. 2021). Duplicate samples were prepared using non-brewed instant holat spice and brewed with $400 \mathrm{~mL}$ of boiling water. Panelists must rinse their mouths with water before every new sample was tested, (Galla et al. 2017).

\section{Statistical analysis}

The study was performed in duplicate, and the mean values and standard deviation (SD) were calculated. An analysis of variance (ANOVA) was used to analyze the data.

\section{RESULTS AND DISCUSSION}

\section{Proximate composition}

The proximate composition of all instant holat spice was presented in Table 2. The moisture content of four formulations varied and differed significantly $(\mathrm{P}<0.05)$. Formulation $4(\mathrm{~F} 4)$ had the highest moisture content $(18.55$ $\pm 0.17 \%)$, while $\mathrm{F} 1$ had the lowest $(9.15 \pm 0.11 \%)$. It might be due to higher content of $P$. emblica bark in F4; therefore, increasing the bark content increases moisture content of instant holat.

Drying time affected moisture content. The increasing drying time result in decreasing moisture content (Idah et al. 2010; Shalini et al. 2017), as in F3-20 (17.89 $\pm 0.02 \%)$, F3-22 (17.25 $\pm 0.30 \%)$, and F3-24 (16.49 $\pm 0.33 \%)$, which have a significantly different moisture content $(\mathrm{P}<0.05)$. However, there was no significant interaction between bark content and drying time on moisture content $(\mathrm{P} \geq 0.05)$. The moisture content of four formulations of instant holat spice meets the requirements of dried food, with moisture content $\leq 25 \%$ (Afolabi 2014).

The ash content of all formulations of instant holat was not significantly different $(\mathrm{P} \geq 0.05)$. F1-22 has the highest ash content $(7.80 \pm 0.01 \%)$, while F4-24 has the lowest one $(7.70 \pm 0.01 \%)$. The results showed that drying time had no effect on the ash content and previous studies (Delgado et al. 2016; Isik et al. 2019; Bikila et al. 2020). The inorganic residue left after the ignition or complete oxidation of organic matter in biological material is referred to as ash (Liu 2019). Ash is a measure of a food ingredient's total mineral content (Bikila et al. 2020). The drying temperature did not affect the mineral content in the material (Manthey and Hall 2007) as well as drying time. It is based on the concept that minerals are not destroyed by heating because they are less volatile than other compounds (Liu 2019).

Table 2 shows that the protein content of the four holat formulations was significantly different $(\mathrm{P}<0.05)$. F1-20 contained the highest protein content $(11.21 \pm 0.08 \%)$ and the lowest protein content was F4-25 (10.42 $\pm 0.02 \%)$. The drying time had no significant effect on protein content as well as interaction of drying time and amount of bark $(\mathrm{P} \geq$ 0.05). Nevertheless, the crude protein content decreased with increasing the drying air temperature, like previous research (Miranda et al. 2010; Aksoy et al. 2019; Isik et al. 2019) while there was a slight difference in drying time had no effect on protein levels. Protein loss might be caused by denaturation or changes in solubility during drying (Miranda et al. 2010; Aksoy et al. 2019; Isik et al. 2019). In addition, a further possible reason for this decrease is the release of amino acids from proteins after denaturation, which might interact with other compounds like as sugars to create melanoidines through the Maillard reaction (Miranda et al. 2010).

Table 1. Formulation of instant holat spice

\begin{tabular}{lcccc}
\hline \multirow{2}{*}{ Ingredients } & \multicolumn{4}{c}{ Formulations } \\
\cline { 2 - 5 } & F1 & F2 & F3 & F4 \\
\hline Bark of Phyllanthus emblica $(\mathrm{g})$ & 15 & 25 & 35 & 45 \\
Onion (g) & 50 & 50 & 50 & 50 \\
Oil (mL) & 15 & 15 & 15 & 15 \\
Garlic (g) & 23 & 23 & 23 & 23 \\
Leeks (g) & 10 & 10 & 10 & 10 \\
Celery (g) & 10 & 10 & 10 & 10 \\
Lemongrass (g) & 7 & 7 & 7 & 7 \\
Ginger (g) & 4 & 4 & 4 & 4 \\
Salt (g) & 3 & 3 & 3 & 3 \\
\hline
\end{tabular}

Note: F1: Formulation 1; F2: Formulation 2; F3: Formulation 3; F4: Formulation 4 
Table 2. Proximate composition of instant holat spice

\begin{tabular}{lcccccc}
\hline $\begin{array}{l}\text { Formulation- } \\
\text { drying time } \\
\text { (hours) }\end{array}$ & Moisture (\%) & Ash $(\%)$ & Protein (\%) & Fat $(\%)$ & $\begin{array}{c}\text { Crude fiber } \\
(\%)\end{array}$ & $\begin{array}{c}\text { Total } \\
\text { carbohydrate }(\%)\end{array}$ \\
\cline { 2 - 7 } F1-20 & $10.15 \pm 0.21^{\mathrm{h}}$ & $7.78 \pm 0.01^{\mathrm{b}}$ & $11.21 \pm 0.08^{\mathrm{a}}$ & $12.14 \pm 0.04^{\mathrm{a}}$ & $13.07 \pm 0.04^{\mathrm{f}}$ & $58.72 \pm 0.33^{\mathrm{c}}$ \\
F1-22 & $9.56 \pm 0.16^{\mathrm{h}}$ & $7.80 \pm 0.01^{\mathrm{a}}$ & $11.14 \pm 0.04^{\mathrm{ab}}$ & $12.09 \pm 0.02^{\mathrm{a}}$ & $13.06 \pm 0.01^{\mathrm{f}}$ & $59.42 \pm 0.22^{\mathrm{b}}$ \\
F1-24 & $9.15 \pm 0.11^{\mathrm{g}}$ & $7.77 \pm 0.01^{\mathrm{b}}$ & $11.08 \pm 0.01^{\mathrm{b}}$ & $11.85 \pm 0.05^{\mathrm{b}}$ & $13.02 \pm 0.01^{\mathrm{f}}$ & $60.15 \pm 0.07^{\mathrm{a}}$ \\
F2-20 & $13.97 \pm 0.01^{\mathrm{f}}$ & $7.75 \pm 0.00^{\mathrm{c}}$ & $10.89 \pm 0.04^{\mathrm{c}}$ & $11.56 \pm 0.03^{\mathrm{c}}$ & $14.62 \pm 0.07^{\mathrm{d}}$ & $55.82 \pm 0.11^{\mathrm{e}}$ \\
F2-22 & $13.82 \pm 0.01^{\mathrm{e}}$ & $7.75 \pm 0.00^{\mathrm{c}}$ & $10.84 \pm 0.01^{\mathrm{c}}$ & $11.36 \pm 0.06^{\mathrm{d}}$ & $14.55 \pm 0.01^{\mathrm{de}}$ & $56.23 \pm 0.08^{\mathrm{e}}$ \\
F2-24 & $12.30 \pm 0.37^{\mathrm{e}}$ & $7.74 \pm 0.00^{\mathrm{cd}}$ & $10.82 \pm 0.03^{\mathrm{c}}$ & $11.15 \pm 0.04^{\mathrm{e}}$ & $14.48 \pm 0.03^{\mathrm{e}}$ & $57.99 \pm 0.44^{\mathrm{d}}$ \\
F3-20 & $17.89 \pm 0.02^{\mathrm{b}}$ & $7.73 \pm 0.01^{\mathrm{de}}$ & $10.64 \pm 0.04^{\mathrm{d}}$ & $11.03 \pm 0.01^{\mathrm{f}}$ & $15.89 \pm 0.05^{\mathrm{c}}$ & $52.70 \pm 0.01^{\mathrm{hi}}$ \\
F3-22 & $17.25 \pm 0.30^{\mathrm{c}}$ & $7.74 \pm 0.01^{\mathrm{de}}$ & $10.57 \pm 0.02^{\mathrm{e}}$ & $10.97 \pm 0.02^{\mathrm{fg}}$ & $15.83 \pm 0.02^{\mathrm{c}}$ & $53.49 \pm 0.35^{\mathrm{g}}$ \\
F3-24 & $16.49 \pm 0.33^{\mathrm{d}}$ & $7.73 \pm 0.00^{\mathrm{de}}$ & $10.53 \pm 0.01^{\mathrm{e}}$ & $10.90 \pm 0.00^{\mathrm{g}}$ & $15.81 \pm 0.01^{\mathrm{c}}$ & $54.35 \pm 0.34^{\mathrm{f}}$ \\
F4-20 & $18.55 \pm 0.17^{\mathrm{a}}$ & $7.72 \pm 0.00^{\mathrm{e}}$ & $10.43 \pm 0.05^{\mathrm{f}}$ & $10.67 \pm 0.11^{\mathrm{h}}$ & $17.00 \pm 0.01^{\mathrm{a}}$ & $52.62 \pm 0.33^{\mathrm{i}}$ \\
F4-22 & $18.42 \pm 0.10^{\mathrm{a}}$ & $7.71 \pm 0.01^{\mathrm{f}}$ & $10.44 \pm 0.01^{\mathrm{f}}$ & $10.57 \pm 0.02^{\mathrm{i}}$ & $16.95 \pm 0.09^{\mathrm{a}}$ & $52.87 \pm 0.07^{\mathrm{hi}}$ \\
F4-25 & $18.14 \pm 0.05^{\mathrm{ab}}$ & $7.70 \pm 0.01^{\mathrm{f}}$ & $10.42 \pm 0.02^{\mathrm{f}}$ & $10.52 \pm 0.02^{\mathrm{i}}$ & $16.84 \pm 0.05^{\mathrm{b}}$ & $53.23 \pm 0.05^{\mathrm{gh}}$ \\
\hline N02 The composition &
\end{tabular}

Note: The data represent the mean and standard deviation of duplicate samples. Means in the same column with the same letters are not significantly different $(\mathrm{P} \geq 0.05)$

The fat content differed significantly $(\mathrm{P}<0.05)$. The highest fat content was in F1-20 (12.14 $\pm 0.04 \%)$ and the lowest was in F4-25 $(10.52 \pm 0.02)$. The decrease in fat content was caused by a decrease in the oil percentage. The oil percentage in F4 was $8.98 \%$. Drying time had a significant effect on fat content, i.e., F2-20 (11.56 \pm $0.03 \%)$, F2-22 $(11.36 \pm 0.06 \%)$, and F2-24 (11.15 \pm $0.04 \%)$. This can be caused by volatile compounds in materials such as essential oils (Adak et al. 2018; Choudhary and Grover 2019), which evaporate during the drying process (Marey and Shoughy 2016). The longer the drying is carried out, the more compounds are lost. A study by Delgado et al. (2016) showed that the fat content had decreased with increasing drying time. Increasing the drying temperature resulted in higher reduction of crude fat (Miranda et al. 2010; Marey and Shoughy 2016). The fat content of instant pindang seasoning powder and seasoning with Tom Yam flavor was between 1-2 \% (Phornphisutthimas 2010; Mareta et al. 2019), whilst fat content in instant holat spice was higher due to the higher proportion of oil in formulations.

Crude fiber in the four holat formulas was significantly different due to the amount of bark $(\mathrm{P}<0.05)$. F4-20 had the highest crude fiber content $(17.00 \pm 0.01 \%)$, while F124 had the lowest one $(13.02 \pm 0.01 \%)$. Drying time did not significantly affect crude fiber content $(P \geq 0.05)$. Because bark is used as an ingredient in instant holat spice, therefore crude fiber content was higher than in seasoning with Tom Yam flavor (4.33\%) (Phornphisutthimas 2010).

The four holat formulas had significantly different total carbohydrate content $(\mathrm{P}<0.05)$ (Table 2.). F4-20 had the lowest total carbohydrate content $(52.62 \pm 0.33 \%)$, and F124 had the highest one $(60.15 \pm 0.07 \%)$. The amount of moisture content, ash, fat, and protein in instant holat spice affected the total carbohydrate content. The test results showed low moisture content while high total carbohydrate content, the same thing was also in the study of Miranda et al. (2010).

\section{Microbiological analysis}

There was no microbial growth (data not shown) either in total plate count, and yeast and mold count. Antimicrobial compounds in spice ingredients, such as bark of Phyllanthus emblica have (Dhale and Mogle 2011; Adak et al. 2018), onion (Ye et al. 2013), garlic (Ross et al. 2001; Liu et al. 2021; Prajapati et al. 2021), and others, can prevent microbial growth. It has been reported that the bark of Phyllanthus emblica can inhibit the growth of Staphylococcus aureus, Bacillus subtilis, Pseudomonas aeruginosa, Escherichia coli, and Salmonella typhi which is thought to be caused by the presence of tannins and flavonoids (Dhale and Mogle 2011; Adak et al. 2018). Moreover, onions have also been shown to have antimicrobial activity against bacteria (E. coli, B. subtilis, and $S$. aureus), yeasts ( $R$. glutinis, S. cerevisiae, and $C$. tropicalis), and molds (A. niger, M. purpureus, and A. terreus), that is thought to be affected by methyl 5methylfuryl sulfide $(18.30 \%)$, methyl 3,4-dimethyl-2-thi $(9.72 \%)$ (Ye et al. 2013). In addition, allicin activity is the main activity of garlic constituents, and there is a lot of evidence that allicin can inhibit different organisms like gram-positive and gram-negative bacteria (Ross et al. 2001; Prajapati et al. 2021).

\section{Sensory characteristics}

Sensory characteristics of instant holat spice were evaluated before and after brewing. Evaluation before brewing was carried out to determine consumers' first perceptions of instant holat spices, while testing after brewing was carried out to determine the preference of customers. There is some evidence that the temperature and length of the brewing process affect constituent extraction and the brewing process caused different flavors of green tea (Lee and Chambers 2009). Researchers discovered that the amounts of tannin, free sugar, and total nitrogen in green tea enhanced as the water temperature and brewing time risen in research to evaluate how different brewing changes occur in green tea constituents (Lee et al. 1989). The result of this extraction process causes changes in sensory characteristics. Table 3 showed the sensory 
characteristics of non-brewed instant holat spice, for which aroma, color, and overall acceptability were not significantly different $(\mathrm{P} \geq 0.05)$. Sensory characteristics did not differ significantly due to low concentration of bark in the formulations, this result was also similar in yogurt studies (Noh et al. 2013; Hekmat et al. 2015).

The highest score of aroma, color, and overall acceptability was found at F1-24 (5.25 \pm 1.35$),$ F4-22 (5.38 $\pm 1.14)$, and F4-24 (5.58 \pm 1.03$)$, respectively, while the lowest were found at F2-20 (4.58 \pm 1.17$),$ F1-22 (3.56 \pm $1.35)$, and F1-22 (4.48 \pm 1.28$)$. Figure 1 showed that the color and overall characteristics of F4 are the most favored by the panelists, whereas F1 is the least preferred. F4 contained the highest amount of $P$. emblica bark in instant holat spice that may has the most astringent flavor (Madhuri et al. 2011; Vasant et al. 2013). Due to its astringent flavor, holat has its own unique flavor and socalled holat (Damanik and Sinaga 2020; Pulungan et al. 2020). Based on the sensory characteristics evaluation of non-brewed holat instant spice, therefore F4-24 is the most preferred formula by the panelists.

Table 4 reveals that the sensory characteristics of brewed instant holat spice were not significantly different in terms of aroma, color, taste, and overall acceptability (P $\geq 0.05$ ). Figure 2 showed the results of the sensory analysis of the aroma, color, taste, and acceptability of the whole sample of brewed instant holat spice.

Table 3. Sensory characteristics of non-brewed instant holat spice

\begin{tabular}{llll}
\hline $\begin{array}{l}\text { Formulation- } \\
\text { drying time } \\
\text { (hours) }\end{array}$ & \multicolumn{3}{c}{ Sensory characteristics } \\
\cline { 2 - 4 } & Aroma & \multicolumn{1}{c}{ Color } & $\begin{array}{c}\text { Overall } \\
\text { acceptability }\end{array}$ \\
\hline F1-20 & $4.58 \pm 1.30^{\mathrm{c}}$ & $5.03 \pm 0.96^{\mathrm{abc}}$ & $5.30 \pm 0.85^{\mathrm{ab}}$ \\
F1-22 & $4.98 \pm 1.10^{\mathrm{abc}}$ & $3.56 \pm 1.35^{\mathrm{g}}$ & $4.48 \pm 1.28^{\mathrm{d}}$ \\
F1-24 & $5.25 \pm 1.35^{\mathrm{a}}$ & $3.59 \pm 1.29^{\mathrm{g}}$ & $4.58 \pm 1.28^{\mathrm{d}}$ \\
F2-20 & $4.58 \pm 1.17^{\mathrm{c}}$ & $4.77 \pm 0.93^{\mathrm{bcd}}$ & $4.88 \pm 1.11^{\mathrm{bcd}}$ \\
F2-22 & $4.75 \pm 0.87^{\mathrm{bcc}}$ & $4.28 \pm 1.12^{\mathrm{de}}$ & $4.82 \pm 1.10^{\mathrm{bcd}}$ \\
F2-24 & $4.65 \pm 1.03^{\mathrm{bc}}$ & $4.74 \pm 1.23^{\mathrm{bcde}}$ & $4.91 \pm 0.98^{\mathrm{bcd}}$ \\
F3-20 & $4.93 \pm 1.19^{\mathrm{abc}}$ & $4.18 \pm 1.10^{\mathrm{ef}}$ & $4.82 \pm 1.18^{\mathrm{bcd}}$ \\
F3-22 & $4.78 \pm 1.07^{\mathrm{abc}}$ & $4.62 \pm 1.07^{\mathrm{cde}}$ & $4.91 \pm 0.63^{\mathrm{bcd}}$ \\
F3-24 & $4.88 \pm 1.02^{\mathrm{abc}}$ & $4.33 \pm 1.15^{\mathrm{de}}$ & $4.76 \pm 1.00^{\mathrm{bcd}}$ \\
F4-20 & $5.20 \pm 1.18^{\mathrm{ab}}$ & $3.69 \pm 1.26^{\mathrm{fg}}$ & $4.64 \pm 1.14^{\mathrm{cd}}$ \\
F4-22 & $4.63 \pm 1.13^{\mathrm{bc}}$ & $5.38 \pm 1.14^{\mathrm{a}}$ & $5.21 \pm 0.99^{\mathrm{abc}}$ \\
F4-25 & $4.90 \pm 1.06^{\mathrm{abc}}$ & $5.23 \pm 0.99^{\mathrm{ab}}$ & $5.58 \pm 1.03^{\mathrm{a}}$ \\
\hline Not
\end{tabular}

Note: The data represent the mean and standard deviation of duplicate samples. Means in the same column with the same letters are not significantly different $(\mathrm{p} \geq 0.05)$

Table 4. Sensory characteristics of brewed instant holat spice

\begin{tabular}{|c|c|c|c|c|}
\hline \multirow{2}{*}{$\begin{array}{l}\text { Formulation-drying time } \\
\text { (hours) }\end{array}$} & \multicolumn{4}{|c|}{ Sensory characteristics } \\
\hline & Aroma & Color & Taste & Overall acceptability \\
\hline F1-20 & $4.08 \pm 1.21^{\mathrm{b}}$ & $4.08 \pm 1.42^{\mathrm{bcd}}$ & $3.03 \pm 1.18^{\mathrm{d}}$ & $3.63 \pm 1.33^{\mathrm{c}}$ \\
\hline F1-22 & $4.73 \pm 1.06^{\mathrm{a}}$ & $3.45 \pm 1.13^{\mathrm{e}}$ & $4.15 \pm 1.18^{\mathrm{ab}}$ & $4.35 \pm 0.77^{\mathrm{ab}}$ \\
\hline F1-24 & $4.60 \pm 1.22^{\mathrm{a}}$ & $3.98 \pm 1.33^{\text {cde }}$ & $4.05 \pm 1.38^{\mathrm{abc}}$ & $4.18 \pm 0.90^{\mathrm{ab}}$ \\
\hline $\mathrm{F} 2-20$ & $4.78 \pm 0.83^{\mathrm{a}}$ & $4.28 \pm 1.06^{\mathrm{bcd}}$ & $4.28 \pm 1.28^{\mathrm{a}}$ & $4.40 \pm 0.96^{\mathrm{ab}}$ \\
\hline $\mathrm{F} 2-22$ & $4.58 \pm 0.90^{\mathrm{a}}$ & $3.88 \pm 0.85^{\mathrm{de}}$ & $4.10 \pm 1.14^{\mathrm{ab}}$ & $4.28 \pm 0.96^{\mathrm{ab}}$ \\
\hline $\mathrm{F} 2-24$ & $4.83 \pm 0.98^{\mathrm{a}}$ & $4.58 \pm 1.11^{\mathrm{ab}}$ & $4.21 \pm 0.86^{\mathrm{ab}}$ & $4.65 \pm 0.95^{\mathrm{a}}$ \\
\hline F3-20 & $4.73 \pm 0.93^{\mathrm{a}}$ & $4.13 \pm 0.97^{\mathrm{bcd}}$ & $4.26 \pm 1.12^{\mathrm{ab}}$ & $4.53 \pm 1.11^{\mathrm{ab}}$ \\
\hline F3-22 & $4.65 \pm 1.08^{\mathrm{a}}$ & $4.58 \pm 0.98^{\mathrm{ab}}$ & $4.15 \pm 1.14^{\mathrm{ab}}$ & $4.55 \pm 1.15^{\mathrm{ab}}$ \\
\hline F3-24 & $4.75 \pm 1.06^{\mathrm{a}}$ & $4.48 \pm 0.88^{\mathrm{abc}}$ & $4.36 \pm 1.27^{\mathrm{a}}$ & $4.58 \pm 1.06^{\mathrm{ab}}$ \\
\hline F4-20 & $4.68 \pm 1.21^{\mathrm{a}}$ & $3.53 \pm 1.41^{\mathrm{e}}$ & $3.64 \pm 1.20^{\mathrm{bc}}$ & $4.13 \pm 1.11^{\mathrm{ab}}$ \\
\hline F4-22 & $4.28 \pm 1.13^{\mathrm{ab}}$ & $4.15 \pm 1.14^{\mathrm{bcd}}$ & $3.49 \pm 1.21^{\mathrm{cd}}$ & $4.03 \pm 1.29^{\mathrm{bc}}$ \\
\hline F4-25 & $4.63 \pm 1.13^{\mathrm{a}}$ & $4.85 \pm 1.08^{\mathrm{a}}$ & $3.64 \pm 1.40^{\mathrm{bc}}$ & $4.68 \pm 1.21^{\mathrm{a}}$ \\
\hline
\end{tabular}

Note: The data represent the mean and standard deviation of duplicate samples. Means in the same column with the same letters are not significantly different $(\mathrm{p} \geq 0.05)$

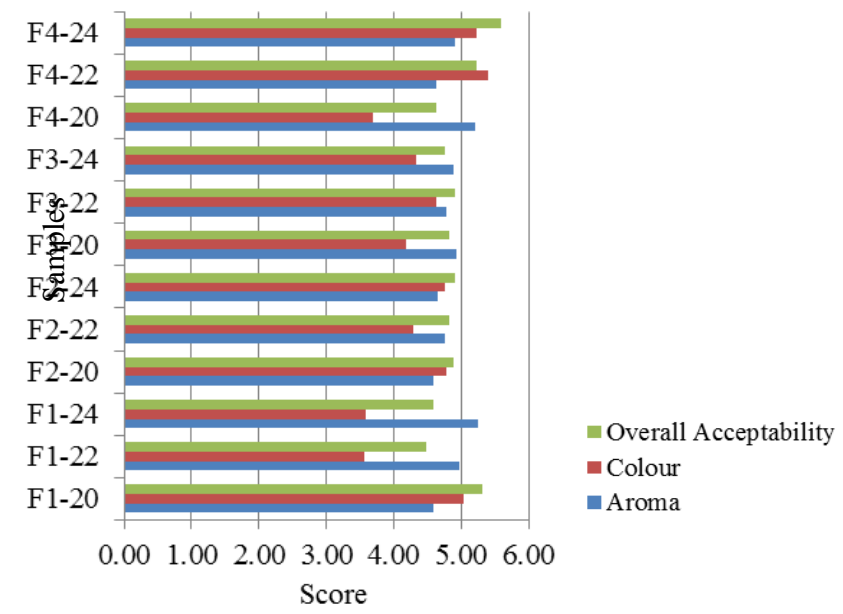

Figure 1. The diagram of the score of sensory characteristics of non-brewed instant holat spice

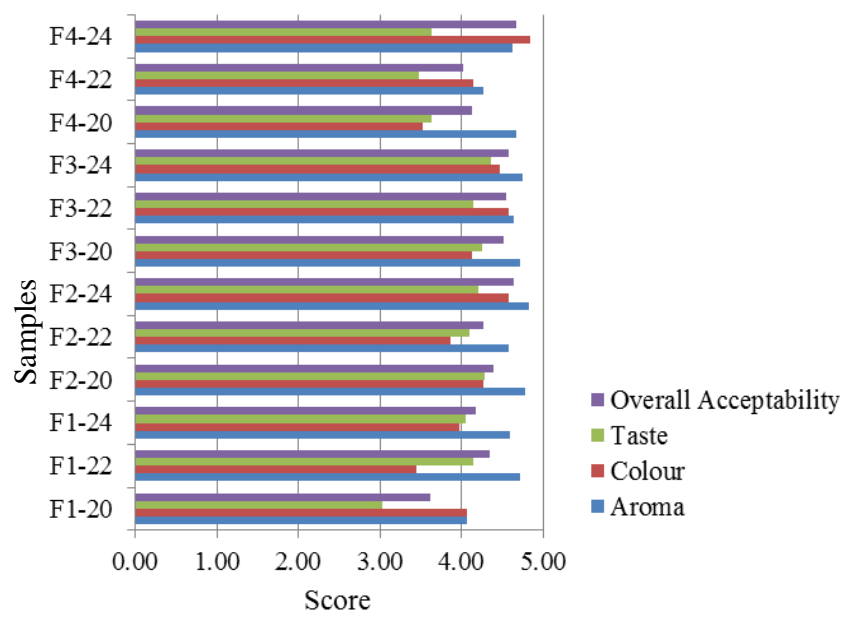

Figure 2. The diagram of the score sensory characteristics of brewed instant holat spice 


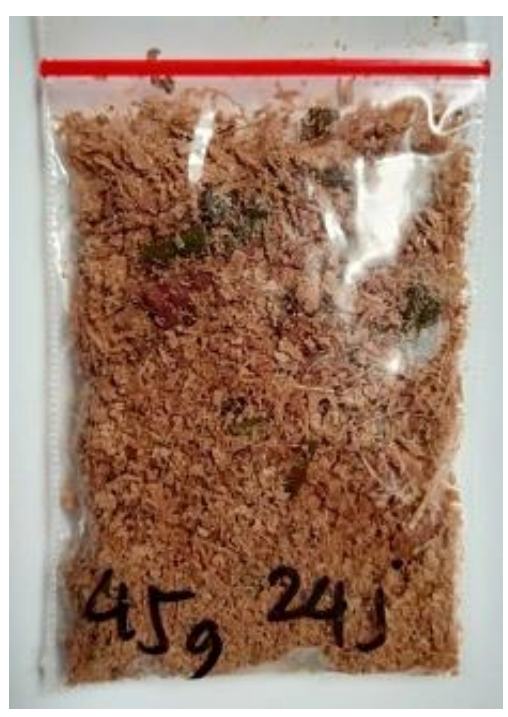

Figure 3. The product of F4-24 instant holat spice

Samples with high scores of aroma, color, taste, and overall acceptability were F2-24 (4.83 \pm 0.98$)$, F4-24 (4.85 $\pm 1.08), \mathrm{F} 3-24(4.36 \pm 1.27)$, and F4-24 (4.68 \pm 1.21$)$, respectively, while samples with the low score were F1-20 $(4.08 \pm 1.21), \mathrm{F} 1-22(3.45 \pm 1.13), \mathrm{F} 1-20$ (3.03 \pm 1.18$)$, and F1-20 $(3.63 \pm 1.33)$. In general, F4 which has the highest amount of P.emblica bark was the most preferred formula, while F1 was the least preferred. However, the panelists' overall acceptance scores decreased after brewing. F4-24 has a score of $5.58 \pm 1.03$ before brewing to $4.68 \pm 1.21$ after brewing. This may be related to the changes of chemical content in instant holat spice after brewing. As in espresso, the higher the brewing temperature and time, the lesser the sensory quality (Batali et al. 2020; Klotz et al. 2020). Based on the average outcomes and the overall sensory analysis, it is concluded that F4-24 (Figure 3) is the most preferred formulation of instant holat spice.

\section{ACKNOWLEDGEMENTS}

The study was financially supported by the Research Institute, Universitas Sumatera Utara, Medan, Indonesia.

\section{REFERENCES}

Adak S, Chakraborty D, Maji HS, Basu S, Roy P, Mitra S, Goswami A. 2018. Comparison of the antimicrobial activity of the phytoconstituents obtained from the stem bark and leaf extracts of Phyllanthus emblica L. against different strains of Staphylococcus aureus and Salmonella typhi. Res J Pharm Pharmacodynamics 10 (2): 53-60. DOI: 10.5958/2321-5836.2018.00009.5.

Afolabi IS. 2014. Moisture migration and bulk nutrients interaction in a drying food systems: a review. Food Nutr Sci 58 (8): 692-714. DOI: 10.4236/fns.2014.58080.

Ahmad B, Hafeez N, Rauf A, Bashir S, Linfang H, Rehman MR, Rengasamy KRR. 2021. Phyllanthus emblica: A comprehensive review of its therapeutic benefits. South Afr J Bot 138: 278-310. DOI: 10.1016/j.sajb.2020.12.028
Aksoy A, Karasu S, Akcicek A, Kayacan S. 2019. Effects of different drying methods on drying kinetics, microstructure, color, and the rehydration ratio of minced meat. Foods 8 (6): 216. DOI: 10.3390/foods8060216

Ali MA, Hasan SMK, Mahomud MS, Sayed MA. 2012. Processing and storage of instant cooked rice. Bangladesh Res Publ J 7 (3): 300-305.

AOAC. 2011. Official methods of analysis of the association of official analytical chemists international. In: Horwitz W, Latimer GW (eds.) Recovery Studies. Association of Analytical Communities, Gaithersburg, MD, USA.

Batali M, Frost S, Lebrilla C, Ristenpart W, Guinard JX. 2020. Sensory and monosaccharide analysis of drip brew coffee fractions versus brewing time. J Sci Food Agric 100 (7): 2953-2962. DOI: $10.1002 /$ jsfa. 10323

Bikila AM, Tola Y, Esho TB, Forsido SF. 2020. Effect of pre-drying treatment and drying temperature on proximate composition, mineral contents, and thermophysical properties of anchote (Coccinia abyssinica (Lam.) Cogn.) flour. Food Sci Nutr 8 (10): 5532-5544. DOI: $10.1002 / \mathrm{fsn} 3.1860$

Chaphalkar R, Apte KG, Talekar Y, Ojha SK, Nandave M. 2017. Antioxidants of Phyllanthus emblica L. bark extract provide hepatoprotection against ethanol-induced hepatic damage: a comparison with silymarin. Oxidative Med Cell Longevity 1-10. DOI: $10.1155 / 2017 / 3876040$

Choudhary M, Grover, K. 2019. Amla (Emblica officinalis L.) oil. Fruit Oils: Chem Funct 875-882. DOI: 10.1007/978-3-030-12473-1_48

Damanik R, Sinaga W. 2020. Dayok na binatur (Holat): Simalungun Traditional Food. Paper presented at the Talenta Conference Series: Local Wisdom, Social, and Arts (LWSA).

Dasaroju S, Gottumukkala KM. 2014. Current trends in the research of Emblica officinalis (Amla): a pharmacological perspective. Intl J Pharm Sci Rev Res 24 (2): 150-159.

Deepak P, Gopal GV. 2014. GC-MS analysis of ethyl acetate extract of Phyllanthus emblica L. bark. Brit Biomed Bull 2 (2): 285-292.

Delgado T, Pereira JA, Casal S, Ramalhosa E. 2016. Effect of drying on color, proximate composition and drying kinetics of sliced chestnuts. J Food Process Eng 39 (5): 512-520. DOI: 10.1111/jfpe.12244

Dhale D, Mogle U. 2011. Phytochemical screening and antibacterial activity of Phyllanthus emblica (L.). Sci Res Rep 1 (3): 138-142.

Dhiman AK, Negi V, Attri S, Ramachandran P. 2017. Development and standardization of instant food mixes from dehydrated pumpkin and pumpkin seed powder (Cucurbita moschata Duch ex Poir). Intl J 10.23910/IJBSM/2017.8.2.1792

Gaire BP, Subedi L. 2014. Phytochemistry, pharmacology and medicinal properties of Phyllanthus emblica Linn. Chin J Integr Med 1-8. DOI: 10.1007/s11655-014-1984-2

Galla NR, Pamidighantam PR, Karakala B, Gurusiddaiah MR, Akula S. 2017. Nutritional, textural and sensory quality of biscuits supplemented with spinach (Spinacia oleracea L.). Intl J Gastronom Food Sci 7: 20-26. DOI: 10.1016/j.ijgfs.2016.12.003

Hekmat S, Morgan K, Soltani M, Gough R. 2015. Sensory evaluation of locally-grown fruit purees and inulin fibre on probiotic yogurt in Mwanza, Tanzania and the microbial analysis of probiotic yogurt fortified with Moringa oleifera. J Health, Population Nutr 33 (1): 60.

Huabprasert S, Kasetsinsombat K, Kangsadalampai K, Wongkajornsilp A, Akarasereenont P, Panich U, Laohapand T. 2012. The Phyllanthus emblica Linn infusion carries immunostimulatory activity in a mouse model. J Med Assoc Thai 95 (1): 24-31.

Iamsaard S, Arun S, Burawat J, Sukhorum W, Wattanathorn J, Nualkaew S, Sripanidkulchai B. 2014. Phenolic contents and antioxidant capacities of Thai-Makham Pom (Phyllanthus emblica L.) aqueous extracts. J Zhejiang Univ-Sci B (Biomed Biotechnol) 15 (4): 405-408. DOI: 10.1631/jzus.B1300284

Idah PA, Musa JJ, Olaleye ST. 2010. Effect of temperature and drying time on some nutritional quality parameters of dried tomatoes. AU J Technol 14 (1): 25-32.

Isik A, Ozdemir M, Doymaz I. 2019. Effect of hot air drying on quality characteristics and physicochemical properties of bee pollen. Food Sci Technol 39 (1): 224-231. DOI: 10.1590/fst.02818.

Khan KH. 2009. Roles of Emblica officinalis in medicine - A Review. Bot Res Int1 2 (4): 218-228.

Khoiriyah U, Pasaribu N, Hannum S. 2015. Distribusi Phyllanthus emblica L. di Sumatera Utara Bagian Selatan. Biosfera 32 (2): 98102. DOI: 10.20884/1.mib.2015.32.2.300. [Indonesian] 
Klotz JA, Winkler G, Lachenmeier DW. 2020. Influence of the brewing temperature on the taste of espresso. Foods 9 (1): 36. DOI: 10.3390/foods 9010036.

Kumar KPS, Bhowmik D, Dutta A, Yadav AP, Paswan S, Srivastava S, Deb L. 2012. Recent trends in potential traditional Indian herbs Emblica officinalis and its medicinal importance. J Pharmacog Phytochem 1 (1): 24-32.

Lee J, Chambers D. 2009. Sensory descriptive evaluation: brewing methods affect flavour of green tea. Asian J Food Agro-Indust 2 (4): 427-439.

Lee M-G, Lee S-W, Kim S-S, Lee S-H, Oh S-L. 1989. Changes in tasting constituents (tannin, free sugar, total nitrogen) of green tea by leaching condition. J Korean Soc Food Cult 4 (4): 411-416.

Liu J, Mahmood MS, Abbas RZ, Dillawar A, Nawaz Z, Luqman M, Rafique A. 2021. Therapeutic appraisal of ethanolic and aqueous extracts of clove (Syzygium aromaticum) and garlic (Allium sativum) as antimicrobial agent. Pak J Agric Sci 58 (1): 245-251.

Liu K. 2019. Effects of sample size, dry ashing temperature and duration on determination of ash content in algae and other biomass. Algal Res 40: 101486. DOI: 10.1016/j.algal.2019.101486.

Madhuri S, Pandey G, Verma K. 2011. Antioxidant, immunomodulatory and anticancer activities of Emblica officinalis: an overview. Intl Res J Pharm 2 (8): 38-42.

Manthey FA, Hall CA. 2007. Effect of processing and cooking on the content of minerals and protein in pasta containing buckwheat bran flour. J Sci Food Agric 87 (11): 2026-2033. DOI: 10.1002/jsfa.2953.

Mareta D, Setiaboma W, Fitriani V. 2019. Study of making and characteristics of instant pindang seasoning powder using foam-mat drying method. IOP Conf Ser: Earth Environ Sci 258 (1): 012002. DOI: $10.1088 / 1755-1315 / 258 / 1 / 012002$.

Marey S, Shoughy M. 2016. Effect of temperature on the drying behavior and quality of citrus peels. Intl J Food Eng 12 (7): 661-671. DOI: 10.1515/ijfe-2015-0296.

Maser WH, Marsella E. 2019. Preparation of instant holat spices with two formulas and sensory evaluation. Intl J Food Sci Nutr 4 (2): 16-18

Maturin L, Peeler JT. 2001. Aerobic Plate Count. Bacteriological Analytical Manual Online. Center for Food Safety and Applied Nutrition. US Food and Drug Administration, Washington DC, USA.

Miranda M, Vega-Gálvez A, López J, Parada G, Sanders M, Aranda M, Scala KD. 2010. Impact of air-drying temperature on nutritional properties, total phenolic content and antioxidant capacity of quinoa seeds (Chenopodium quinoa Willd.). Indust Crops Prod 32 (3): 258263. DOI: 10.1016/j.indcrop.2010.04.019.

Monteiro MLG, Mársico ET, Lázaro CA, Ribeiro ROR, Jesus RS, ConteJúnior CA. 2014. Flours and instant soup from tilapia wastes as healthy alternatives to the food industry. Food Sci Technol Res 20 (3): 571-581. DOI: 10.3136/fstr.20.571.

Munasinghe M, Jayawardena JAEC, Liyanage R, Katukurunda KGSC. 2015. Assessment of consumption pattern and awareness of fast/instant foods among university students in Sri Lanka. Intl J Innov Res Technol 2 (5): 8-11.

Noh HJ, Seo HM, Lee JH, Chang YH. 2013. Physicochemical and sensory properties of yogurt supplemented with corni fructus during storage. Preventive Nutr Food Sci 18 (1): 45. DOI: 10.3746/pnf.2013.18.1.045

Paluseri DD, Putra SA, Hutama HS, Fajri M. 2017. Warisan Budaya Takbenda Indonesia Penetapan Tahun 2017. Direktorat Warisan dan Diplomasi Budaya, Direktorat Jenderal Kebudayaan, Kementerian Pendidikan dan Kebudayaan, Jakarta. [Indonesian]

Phornphisutthimas S. 2010. Pilot-scale development of dried seasoning with Tom Yam flavour using mushroom as adsorbent. Asian J Food Agro-Indus 3 (3): 335-342.

Prajapati SK, Mishra G, Malaiya A, Jain A, Mody N, Raichur AM. 2021. Antimicrobial application potential of phytoconstituents from turmeric and garlic. Bioactive Nat Prod Pharm Appl 409-435. DOI: 10.1007/978-3-030-54027-2_12.

Priya FF, Islam MS. 2019. Phyllanthus emblica Linn. (Amla) - a natural gift to humans: an overview. J Dis Med Plants 5 (1): 1-9. DOI: 10.11648/j.jdmp.20190501.11.

Pulungan HR, Santosa R, Djatmika D, Wiratno T. 2020. Revealing a traditional nutritious cuisine Mangholat, an SFL approach (a case study of angkola language transitivity in cooking verb). Syst Rev Pharm 11 (11): 632-642.

Ross Z, O'Gara EA, Hill DJ, Sleightholme H, Maslin DJ. 2001. Antimicrobial properties of garlic oil against human enteric bacteria: evaluation of methodologies and comparisons with garlic oil sulfides and garlic powder. Appl Environ Microbiol 67 (1): 475-480. DOI: 10.1128/AEM.67.1.475-480.2001.

Shalini JS, Samsher SC, Kumar V, Chauhan N, Yadav MK. 2017. Effect of moisture content and drying rate on dried aonla shreds during ambient storage. IJCS 5 (4): 362-366.

Sripanidkulchai B, Fangkrathok N. 2014. Antioxidant, antimutagenic and antibacterial activities of extracts from Phyllanthus emblica branches. Songklanakarin J Sci Technol 36 (6): 669-674.

Uji T. 2007. Review: Species diversity of indigenous fruits in Indonesia and its potential. Biodiversitas 8 (2): 157-167. DOI: 10.13057/biodiv/d080217.

Vasant BS, Bhaskarrao DA, Bhanudas SR. 2013. Emblica officinalis-the wonder of ayurvedic medicine. World J Pharm Sci 3 (1): 285-306.

Ye CL, Dai DH, Hu WL. 2013. Antimicrobial and antioxidant activities of the essential oil from onion (Allium cepa L.). Food Control 30 (1): 4853. DOI: 10.1016/j.foodcont.2012.07.033.

Yusof NM, Yee Y, Zakaria Z. 2021. Application of response surface methodology on sensory properties in the development of mushroombased patties from grey oyster mushroom (Pleurotus pulmonarius). IOP Conf Ser Earth Environ Sci 765 (1): 012042. DOI: $10.1088 / 1755-1315 / 765 / 1 / 012042$. 